\title{
Regulations, legislation, and classification
}

\section{B Pless}

\section{Barell matrix, Towner report, and Canada's shame}

\section{REGULATIONS, LEGISLATION, AND CLASSIFICATION}

This issue includes two special features whose importance may be overlooked by some readers. Each is a work in progress, but that there is progress to report in these complex areas is highly encouraging. The first is the report by AharonsonDaniel and her colleagues on the Barell matrix ... the latest attempt to provide a rational, useful classification system for injuries. The second is the paper by John and Liz Towner describing their efforts to assess the importance of legislation, regulation, and national organizations in determining the injury mortality ranking of various countries.

Apart from urging readers to consider both reports carefully, I want to offer some observations of my own on these diverse topics. As is often the case, I hope to stir things up a bit and invite responses.

\section{THE BARELL MATRIX}

Vita Barell was a dynamic Israeli pioneer in the injury prevention field. She died last year at the age of 65. At the time of her death she was head of the Health Services Research Unit in the Department of Health. An important part of her legacy is the matrix for classifying injuries. Classification may not be a captivating topic, but it is essential for most who work in this field. The case of injuries is unlike that of most diseases; to be truly useful we need to know not only what part of the body was hurt, but how the event occurred. In the past, through successive iterations of the International Classifications of Diseases (ICD), this was accomplished by assigning two codes to injuries, the $\mathrm{N}$ code to describe the nature of injury-for example, fracture and an E code to describe the external cause-for example, a car crash. Unfortunately, too many who used ICD were content with $\mathrm{N}$ coding and neglected $\mathrm{E}$ codes. Without E codes, however, the information is virtually useless for prevention.

Like so many great ideas, it is a wonder why no one ever before thought of combining the two codes in a matrix. Perhaps it is because this is more easily said than done, as the long, drawn-out process of reaching international agreement required for this exercise, makes evident. Fortunately, the report in this issue marks the end of the first major step. I urge readers to visit the web site and check the details. Not everyone will be happy with some of the decision. For example, I am mystified how it is possible to classify a head injury involving a concussion as Doubtful, but the data presented appear convincing.

More important than nit picking of this kind, is to encourage readers to familiarize themselves with the matrix and begin using it. Only then will we be able to determine how successful this enterprise is. Personally, I am confident that it represents a major step forward and that although there may be many midstream corrections, there will be no looking back. It is certain to be the tool of choice for injury data analysis and will do much to harmonize data internationally. A deserving epitaph . .

\section{THE TOWNER REPORT}

The Towner paper in this issue initiates a process that is long overdue and of pivotal importance to everyone involved in injury prevention, no matter whether their interest is in children or any other age group. I have long maintained that the most important key to conquering the injury epidemic lies with policymakers. They, in turn, have many tools that can be brought to bear in achieving better results. Apart from leadership, even if only symbolic, they have more mundane tools like legislation, regulation, and, above all, funding.

In spite of the inconclusive bottom line in the Towner report, I remain unshaken in my belief that countries that make full use of these tools will achieve better results ... in the long run. And, perhaps naively, I still believe that among the laggard countries that have failed to establish programs akin to the National Center for Injury Prevention and Control in the US, the main force for reaching this goal will be a powerful, vocal, aggressive child injury prevention child injury advocacy group such as the Child Accident Prevention Trust in the UK or Safe Kids in Canada or the US.

Setting aside the latter question, which remains open and deserves much more attention, what possible explanations can there be for the seemingly disappointing results relating legislation to a country's standing the mortality league tables? The first that comes to mind is that, as the Towners themselves note, the choice of mortality rates as the outcome measure may be seriously flawed and fundamentally misleading. The very fact that the decline seen in most countries in child injury mortality over the last 20 or so years is not related to major primary or secondary preventive measures, forces us to look elsewhere for an explanation. What immediately springs to mind is the likely success (albeit not directly documented) of post-trauma care, or tertiary prevention. In other words, we are keeping injured children alive much better but may well be seeing as many injuries as in the past.

A second possible explanation is the difference between efficacy and effectiveness. My judgment is that most of the measures many advocate have quite good evidence of efficacy ... that is, that under ideal circumstances they work well. Effectiveness is another matter, and it is the reason why we believe an efficacious measure should be required by legislation if voluntary compliance or acceptance does not follow the availability of the measure quickly enough. A good example is seat restraint legislation which resulted in prompt and reasonably large increases in use rates in most countries. Although this argument is a restatement of the Towner's assumptions, what needs to be teased out is what the legislation actually says, and evidence of enforcement. The logic seems so persuasive that I can only conclude that with better data and more refined analyses, the connections being sought by the Towners would be found. Though not, perhaps, using mortality rankings as the dependent variable.

Finally, I need to underscore all the caveats listed by the authors ... and many more . . without wishing to diminish in the least the immense value of this giant first step. We need many more such studies. But while we wait for them we must not lose sight of the fact that at least some of the findings reported by the Towners support my beliefs and preconceptions. I am entitled to these as much as the next person.

\section{A RELATED NOTE: CANADA'S SHAME (OR HOW TO GIVE A PARTY DRESSED SHABBILY)}

One of the advantages (and there are many, believe it or not) of growing old is that it affords the aging academic an element of immunity to reprisals. This in turn gives the elderly license to say or write messages that are unwelcome by those in power. In this column I intend to take advantage of the editor's pen to try 
to shame colleagues, friends, and foes in Health Canada who have failed completely to save me, my fellow Canadians, and themselves (to say nothing of the Health Minister and her provincial counterparts), from tremendous embarrassment.

By the time you read this, the Sixth World Conference on Injury Prevention and Control will have come and gone. But at the time of writing, it is still two months away and I keep hoping for a miracle. Since returning to Canada in 1975, I have tried in vain to persuade successive Health Ministers (and their deputies) to create a division or centre that would permit the Federal Government to lead the way in preventing injuries. I did so through editorials, letters, speeches, pressure on organizations with whom I was involved; and in face to face meetings with seemingly sympathetic ministers. I presented the grim statistics in digestible lumps; showed grisly pictures; pointed to the costs; in turn, I cajoled, charmed, joked, and reasoned.

In the end I resorted to the threat of embarrassment. When it was decided that Canada would be hosting the Sixth World Conference it seemed an unparalleled opportunity to strike again. After all, what sensible Minister would want to welcome visitors from around the world with egg on his or her face. It seemed inconceivable that he (or now, she) would permit Canada to host this meeting dressed shabbily. This is of course a literal statement, but also a metaphor for having nothing to brag about by way of example to less enlightened countries with respect to federal leadership.

I was wrong. The closest we came to getting our act together was the short lived creation of a Secretariat in Health Canada in 1990. Short lived because after a reorganization, new faces and new realities, the Assistant Deputy Minister said that there was no money for injury prevention. Even the entirely inadequate, modest mandate of the Secretariat could not be accomplished. Resignations followed. Ask and they will tell you this creature is still alive; don't ask what the mandate is or what the budget is. The answers, if any, will be shameful and bitterly disappointing.

Pity, not only because this was a chance for Canada to show the way at something possibly more important than ice hockey, but also because for a while the provincial deputy ministers were on side, pushing the Federal Minister to move in the needed direction. They lost interest after September 11 but perhaps it can be resurrected. In spite of all the setbacks, a report on national priorities was produced on their behalf. But with no budget, no leadership, and no structure, it is doomed to gather dust like others before it.

As I write, I am confident our conference will be a good one. But unlike all the previous hosts, with the possible exception of India, we had little to offer that others might wish to emulate beyond our beer and our clean streets. I and my fellow Canadians must hang their heads in shame. We can only hope our Minister shares our embarrassment and will eventually wake up to an epidemic on her watch that kills 10 times as many or more young Canadians as the other diseases with which she and her colleagues appear obsessed.

Injury Prevention 2002;8:89-90

\section{Author's affiliation}

I B Pless, Montreal Children's Hospital and McGill University, Montreal, Canada

Correspondence to: Professor Pless; barry.pless@mcgill.ca

\section{LACUNAE.}

\section{What is America's most dangerous mammal?}

This is the question Ronald Bailey of the online journal Reason asked. Grizzly bears? Certainly Lewis and Clark on their way to the Pacific Ocean in 1804 thought so. In the early 1800s, some 50000 grizzlies roamed the western United States, but their population has now dropped to around 1000 in the lower 48 states. Bears, grizzly and black, killed 128 people in North America in the 20th century. What about mountain lions? Reports that mountain lions lurk in the hills and pick off women trail bikers certainly chill the blood. There have been 14 deaths in North America as a result of mountain lion attacks in the 20 th century. No, there is another creature roaming America's woods that is far more dangerous than these big predators. The most dangerous mammal in North America is ... Bambi. The US Department of Transportation estimates that white tailed deer kill around 130 Americans each year simply by causing car accidents. In 1994, these predator deer had a banner year, causing 211 human deaths in car wrecks. There are about 1.5 million deer/vehicle collisions annually, resulting in 29000 human injuries and more than $\$ 1$ billion in insurance claims in addition to the death toll. Deer also carry the ticks that transmit Lyme disease to about 13000 people each year. Economic damage to agriculture, timber, and landscaping by deer totals more than $\$ 1.2$ billion a year. (Contributed by Ian Scott.)

\section{Unintentional gun injuries}

A paper in the Canadian Journal of Public Health (Vol 92, No 5) concludes, not surprisingly perhaps, that owning a gun increases the risk that someone in your household will die unintentionally from that firearm. "Unintentional firearm deaths: can they be reduced by lowering gun ownership levels?" suggests that the answer to this question is yes. Gun ownership in Canada is nothing approaching that in the US, but pockets of the population have significantly higher rates of firearms in the home. (Contributed by Amy Zierler.) 